\title{
APLIKASI TEKNOLOGI FILTRASI UNTUK MENGHASILKAN AIR BERSIH DARI AIR HASIL OLAHAN IPAL DI RUMAH SAKIT ISLAM SURABAYA
}

\author{
Damiyana Krismayasari $^{\star \star}$ ) dan Sugito*)
}

\begin{abstract}
Abstrak :
Peningkatan jumlah pasien dan pelayanan rumah sakit menyebabkan meningkatnya kebutuhan air bersih. Selama ini produksi oulet IPAL belum diberdayakan, oleh karena itu perlu dilakukan penerlitian untuk mengolah air hasil olahan IPAL menjadi air bersih dengan menggunakan teknologi filtrasi. Penelitian ini bertujuan untuk mengkaji air hasil olah IPAL setelah melalui filter untuk memenuhi kebutuhan air bersih rumah sakit . Air olahan IPAL diambil dari air hasil olahan IPAL Rumah Sakit Islam Surabaya. Reaktor filtrasi menggunakan bahan pipa paralon PVC berdiameter 3 inchi berisi multi media pasir silika, zeolit, manganese greensand, dan karbon aktif. Parameter yang diukur adalah parameter air bersih sesuai dengan Permenkes RI no.416/Menkes/Per/IX/1990. Kinerja reaktor diukur dengan membandingkan kualitas sebelum dan sesudah filtrasi. Hasil penelitian menunjukkan air hasil olahan IPAL di Rumah Sakit Islam Surabaya untuk parameter fisik dan kimia baik sehingga memungkinkan untuk diolah lebih lanjut menjadi air bersih. Parameter mikrobiologi harus dilakukan pengolahan lebih lanjut karena melebihi baku mutu air bersih. Penurunan parameter fisik air bersih pada proses filtrasi dipengaruhi oleh besarnya debit. Penurunan parameter kimia pada filter yang menggunakan media pasir silika, zeolit dan karbon aktif efektif menurunkan kadar ammonia sebesar $98 \%$. Filter yang menggunakan media pasir silika, manganese greensand dan karbon aktif efektif menurunkan sulfat sebesar $36 \%$, nitrat sebesar $96 \%$, besi sebesar $64 \%$ dan flourida sebesar $45 \%$. Filter yang menggunakan media pasir silika, zeolit, manganese greensand dan karbon aktif efektif menurunkan kadar mangan sebesar 100\% dan seng sebesar 38\%. Penurunan parameter mikrobiologi pada filter dengan media pasir silica, zeolit, manganese greensand dan karbon aktif efektif menurunkan sebesar 96\%. Tingginya angka Koliform pada penelitian jika dibandingkan dengan baku ini masih perlu dilakukan pengolahan lebih lanjut sehingga bebas dari Koliform sebagai syarat dalam kualitas air bersih. Untuk itu perlu dilakukan treatment desinfeksi guna menghilangkan Koliform. Hasil penelitian dapat bermanfaat bagi upaya penyelamatan lingkungan dari pencemaran air limbah dan upaya menyelamatkan kelestarian sumber daya air, sebagai pertimbangan penelitian yang serupa, dan menjadi alternatif penghematan pemakaian air bersih dan mengurangi pemakaian air PDAM.
\end{abstract}

Kata Kunci : Air Besih, Air Olahan IPAL, Filtrasi.

\section{PENDAHULUAN}

Rumah sakit sebagai tempat berkumpulnya orang melakukan asuhan keperawatan menghasilkan limbah. Rumah sakit merupakan penghasil limbah klinis terbesar (Depkes, 2006) Limbah rumah sakit adalah semua limbah yang dihasilkan dari kegiatan Rumah Sakit dalam bentuk padat, cair, maupun gas yang dapat mengandung mikroorganisme pathogen bersifat infeksius, bahan kimia beracun, dan sebagian bersifat radioaktif (Depkes, 2006). Pengolahan air limbah melalui IPAL merupakan cara / upaya untuk meminimalkan kadar pencemar yang terkandung dalam limbah cair tersebut sehingga dapat memenuhi Baku Mutu dan layak untuk dibuang ke lingkungan maupun dimanfaatkan kembali (Depkes, 2004). Meningkatnya kegiatan keperawatan serta penunjangnya maka meningkat pula kebutuhan air bersih (Kusnaedi, 2010). Pemakaian air bawah tanah yang tinggi dan juga pembatasan pemakaian yang berlebihan sangat membebani rumah sakit dalam hal penyediaan air bersih. Di sisi lain produksi outlet IPAL masih belum didayagunakan. Mengingat kualitas hasil yang memenuhi baku mutu maka produk outlet IPAL sangat memungkinkan untuk diolah kembali menjadi air bersih.

Metode yang digunakan untuk meningkatkan mutu kualitas air hasil olahan IPAL salah satunya adalah dengan teknologi filtrasi (BPPT,2006). Menurut Alamsjah, 2006 ada bermacam-macam teknologi filtrasi yang disarankan untuk memperoleh air bersih.

\footnotetext{
**) Mahasiswa Teknik Lingkungan

*) Dosen Teknik Lingkungan

Universitas PGRI Adi Buana Surabaya
} 
Dalam penelitian ini akan digunakan teknologi filtrasi dengan media Pasir Silika, Zeolit, Manganese greensand dan Karbon Aktif. Penelitian ini bertujuan untuk memenuhi kebutuhan air bersih dengan mengkaji air hasil olahan IPAL terpadukan teknologi filtrasi dengan mengukur parameter air hasil olahan IPAL dan air hasil teknologi filtrasi serta membandingkan air hasil filtrasi dengan kualitas air bersih yang ditetapkan baku mutu. Pengolahan produk outlet IPAL menjadi air bersih diharapkan dapat menghemat pemakaian air bersih dengan menekan pemakaian air bersih dari air sumur maupun PDAM yang berlebihan serta merupakan pemanfaatan sumber daya yang ada (recycle).

\section{METODE PENELITIAN}

1. Rancangan Penelitian

Air hasil olahan IPAL masih dimungkinkan diolah kembali dengan teknologi filtrasi agar kualitasnya semakin meningkat, sehingga bisa menggantikan peran air bersih yang selama ini diambil dari air tanah, bahkan bisa menghemat pemakaian air PDAM. Disain penelitian seperti pada gambar 1.

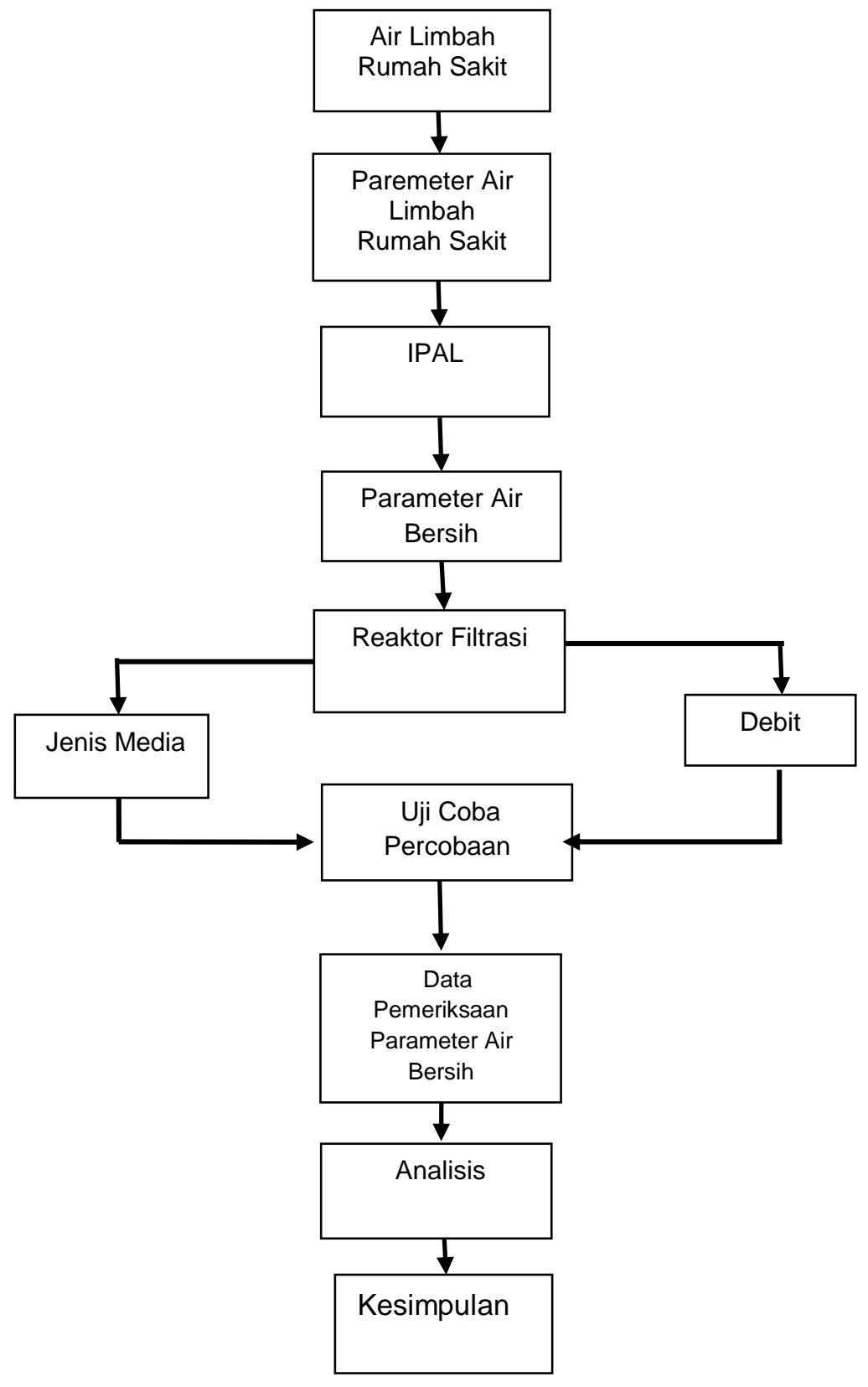

Gambar 1. Rancangan Penelitian 
2. Populasi dan Sampel

Populasi dalam penelitian ini adalah air hasil olahan dari Instalasi Pengolahan

Air Limbah (IPAL) Rumah Sakit Islam Surabaya. Sampel pendahuluan untuk mengetahui karakteristik air sebelum dilakukan percobaan diambil sebanyak 5 liter. Sedangkan sampel untuk percobaan mengambil masing-masing 20 liter untuk percobaan 1 dan percobaan 2.

3. Alat dan Bahan

Kebutuhan bahan yang digunakan untuk membuat reaktor filtrasi seperti pada Tabel 1 .

Tabel 1. Kebutuhan Bahan dan Peralatan Membuat Reaktor Filtrasi

\begin{tabular}{|c|c|c|}
\hline No & $\begin{array}{l}\text { Bahan dan } \\
\text { Peralatan }\end{array}$ & Ukuran Jumlah \\
\hline
\end{tabular}

\begin{tabular}{llcc}
\hline A & Bahan & & \\
1 & Pipa paralon PVC & $\emptyset 3 "$ & 1 lonjor \\
2 & Pipa paralon PVC & $\emptyset 5 / 8 "$ & 2 lonjor \\
3 & Knee & $\emptyset 5 / 8 "$ & 12 buah \\
4 & Lem PVC & - & 1
\end{tabular}

\begin{tabular}{llcc}
5 & Kasa & - & $1 \mathrm{~m}^{2}$ \\
6 & Kain katun & - & $0.5 \mathrm{~m}$ \\
7 & Dop PVC & $\emptyset 3^{\prime \prime}$ & 6 buah \\
B & Peralatan & & \\
1 & Gergaji Besi & - & 2 buah \\
2 & Gunting & - & 1 buah \\
3 & Kertas Gosok Besi & - & 1 buah \\
\hline
\end{tabular}

4. Teknik Pengumpulan Data

Dalam penelitian menggunakan 3 (tiga) reaktor yaitu reaktor 1 berisi pasir silika, zeolit dan karbon aktif, reaktor 2 yang berisi pasir silika, manganese greensand dan karbon aktif serta reaktor 3 yang berisi pasir silika, zeolit, manganese greensand dan karbon aktif. Air hasil olahan IPAL ditampung dalam bak indikator kemudian dipompa ke bak penampung. Dari bak penampung air dialirkan melalui pengatur debit agar debit konstan ke menuju masing-masing reaktor. Skema proses filtrasi peningkatan kualitas air olahan IPAL ditunjukkan pada Gambar 2.

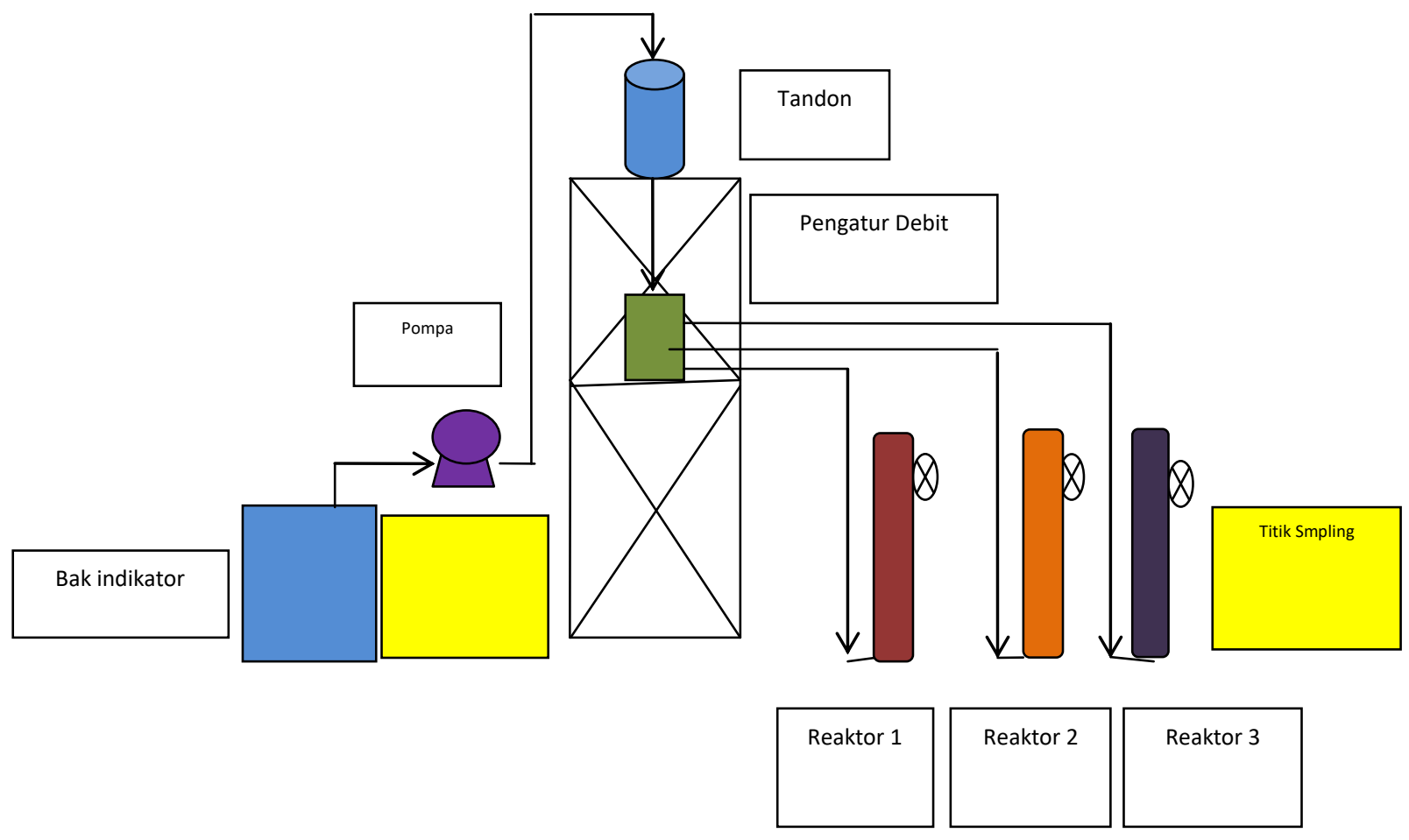

Gambar 2. Proses Filtrasi Peningkatan Kualitas Air Olahan IPAL 
Pengisian media filter dilakukan dengan cara memasukkan media filter melalui bagian atas tabung filter. Dimana ketebalan media dalam reaktor seperti dalam gambar 3.

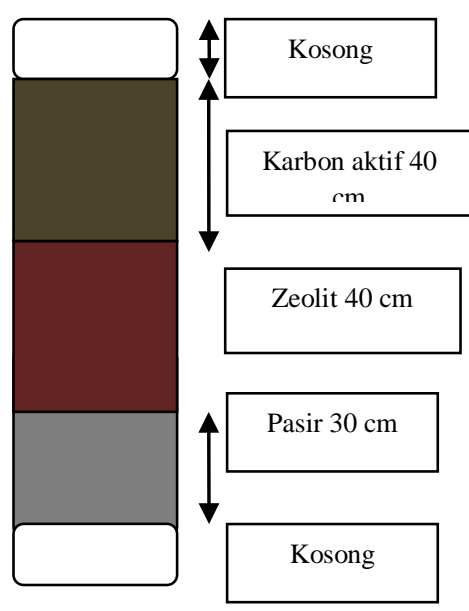

Reaktor I
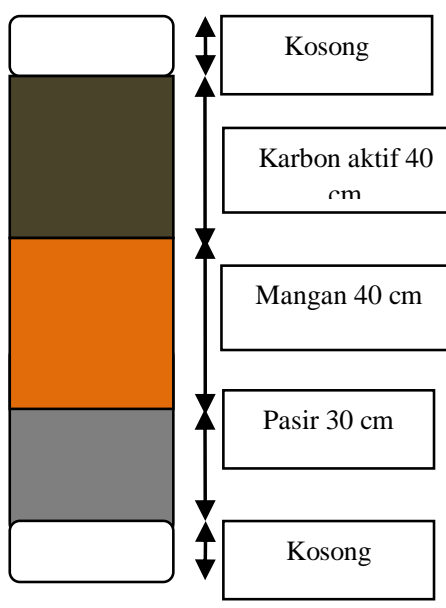

Reaktor II

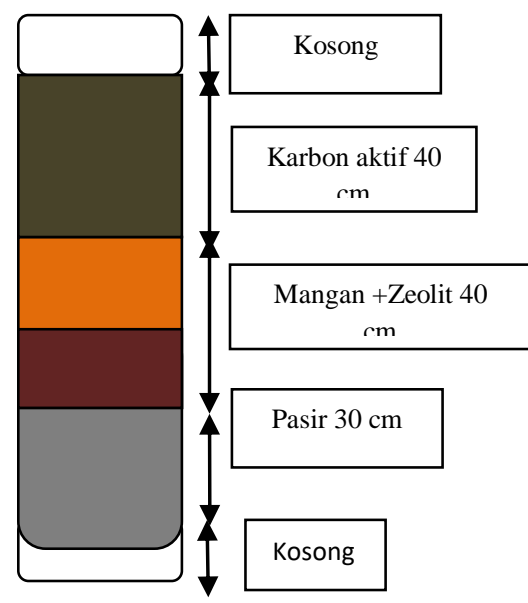

Reaktor III

Gambar 3. Ketebalan Media Dalam Reaktor

Tahap-tahap proses pembuatan instalasi filtrasi dan proses percobaan yang dilakukan adalah sebagai berikut :
1. Rangkaian
dimulai
dengan

mempersiapkan tangga kayu setinggi 2.5

$\mathrm{m}$ sebagai tempat bak penampung air

olahan IPAL Biofilter pada bagian atas dan menyediakan tempat dibagian bawah bak penampung sebagai tempat bak untuk pengatur debit influen air olahan IPAL sehingga air mengalir secara gravitasi ke Reaktor Filtrasi.

2. Meletakkan bak indikator dengan pompa submersible dibawah tangga kayu sebagai tempat air olahan IPAL sebelum dipompakan ke bak pengumpul bagian atas.

3. Masing-masing tabung Reaktor Filtrasi dipasang pada penyangga kayu sehingga tabung reaktor filter dapat berdiri tegak.

4. Menyambungkan pipa PVC $\varnothing 5 / 8 "$ dari bak penampung menuju bak pengatur debit. Serta dari bak penampung debit dibagi menjadi 3 (tiga) outlet menuju ke masing-masing tabung reaktor filter.

5. Melakukan uji coba Instalasi Filtrasi dengan menggunakan air bersih. Untuk memeriksa Instalasi jika terjadi kebocoran sehingga dapat segera dilakukan perbaikan

6. Kembali melakukan uji coba Instalasi Filtrasi dengan menggunakan air produk hasil olahan IPAL dengan debit R1 0.005
$\mathrm{I} / \mathrm{dt}, \mathrm{R} 1=0.00093 \mathrm{l} / \mathrm{dt}$ dan $\mathrm{R} 3=0.0028$ $\mathrm{l} / \mathrm{dt}$.

7. Melakukan percobaan dengan air hasil olahan IPAL.

8. Mengambil sampel pada efluen air bersih setelah mengalami pengolahan dalam reaktor selama setengah jam.

9. Melakukan pengujian parameter.Air bersih yang dihasilkan kemudian diujikan di laboratorium untuk mengetahui kualitas air bersih. Parameter yang diperiksa adalah parameter air bersih sesuai dengan baku. Baku mutu air bersih mengacu pada Peraturan Menteri Kesehatan RI nomor 416 tahun 1990.Pengujian dilakukan di Laboratorium Kualitas Lingkungan ITS Surabaya. Metode yang digunakan untuk penelitian air adalah penelitian air pada buku Baku Uji Air Propinsi Jawa Timur, 1990.

5. Teknik Analisisi Data

Analisis data dalam penelitian ini menggunakan perhitungan efisiensi dengan membandingkan kadar parameter sesudah dan sebelum filtrasi. Selanjutnya disajikan dalam bentuk tabel untuk membandingkan kinerja reaktor dengan variasi media yang berbeda. Data penelitian dibandingkan dengan baku mutu air bersih yang mengacu pada Permenkes $\mathrm{RI}$ no.416/Menkes/Per/IX/1990. 


\section{HASIL PENELITIAN}

1. Analisis Parameter Fisik

Penurunan parameter fisik air bersih dari baku dibandingkan dengan $\mathrm{R} 1, \mathrm{R} 2$, R3 digambarkan dalam grafik pada gambar 5 sebagai berikut :

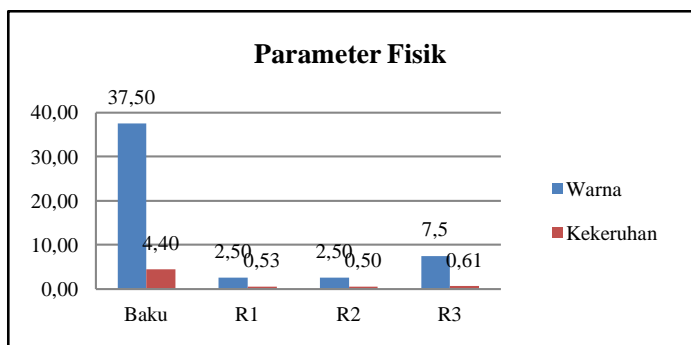

Gambar 5. Grafik Penurunan Parameter Fisik Air Bersih

Gambar 5 menggambarkan bahwa kandungan warna mengalami rata-rata efisiensi penurunan pada R1 sebesar 35 PtCo ( removal 93\%), R2 sebesar 35 PtCo (removal 93\%), dan R3 sebesar 30 PtCo (removal $80 \%$ ). Sedangkan untuk parameter kekeruhan rata-rata efisiensi penurunan pada R1, R2 dan R3 sebesar 3.87 NTU (removal 88\%), 3.9 NTU (removal 89\%) dan 3.795 NTU (removal 86\%).

\section{Analisis Parameter Kimia}

Penurunan parameter kimia air bersih dari air baku dibandingkan dengan $\mathrm{R} 1, \mathrm{R} 2$ dan R3 digambarkan dalam grafik pada gambar 6 .
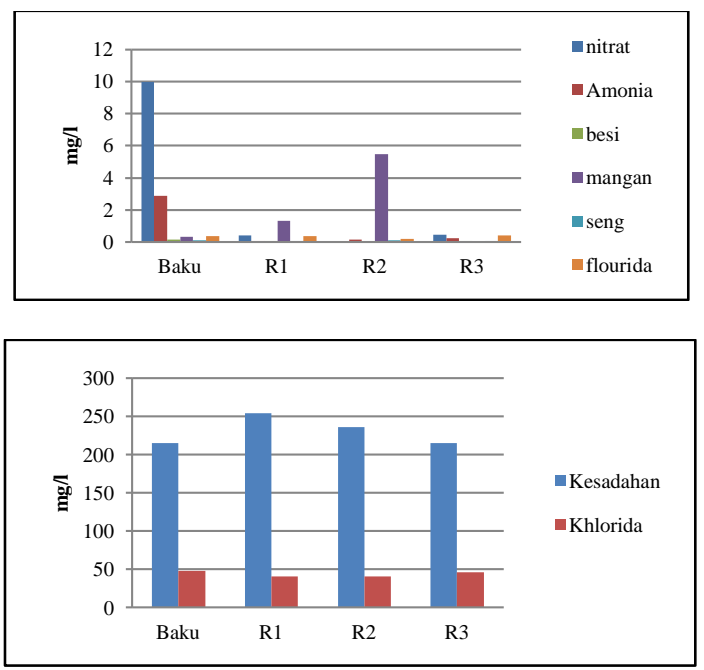

Gambar 6. Grafik Penurunan Parameter Kimia Air Bersih

Berdasarkan grafik pada gambar 6 tren penurunan kadar nitrat pada R1,R2 dan R3 sebesar 9.54 mg/l (removal 96\%)
, $9.935 \mathrm{mg} / \mathrm{l}$ (removal 99\%), $9.48 \mathrm{mg} / \mathrm{l}$ (removal 95\%). Kadar ammonia mengalami penurunan pada R1 sebesar $0.24 \mathrm{mg} / \mathrm{l}$ (removal 98\%), R2 sebesar 2.7 $\mathrm{mg} / \mathrm{l}$ (removal 94\%) dan R3 sebesar 2.63 $\mathrm{mg} / \mathrm{l}$ (removal 98\%). Kadar besi mengalami penurunan pada R1 sebesar $0.07 \mathrm{mg} / \mathrm{l}$ (removal 46\%), R2 sebesar $0.09 \mathrm{mg} / \mathrm{l}$ (removal 64\%) dan R3 sebesar $0.07 \mathrm{mg} / \mathrm{l}$ (removal 50\%). Kadar mangan pada R1 meningkat sebesar $0.98 \mathrm{mg} / \mathrm{l}$, R2 meningkat sebesar $5.13 \mathrm{mg} / \mathrm{l}$ dan R3 mengalami penurunan sebesar $0.35 \mathrm{mg} / \mathrm{l}$ (removal $100 \%$ ). Kadar seng mengalami penurunan pada R1 sebesar $0.025 \mathrm{mg} / \mathrm{l}$ (removal 21\%), R2 sebesar 0.005 (removal 4\%) dan R3 sebesar $0.045 \mathrm{mg} / \mathrm{l}$ (removal 38\%). Penurunan kadar flourida pada R1 sebesar $0.02 \mathrm{mg} / \mathrm{l}$ (removal $5.26 \%$ ), R2 sebesar $0.17 \mathrm{mg} / \mathrm{l}$ (removal $44.74 \%$ ), pada R3 mengalami kenaikan sebesar $0.05 \mathrm{mg} / \mathrm{l}$. Kadar Kesadahan mengalami kenaikan yang sama pada R1dan R2 sebesar $39.29 \mathrm{mg} / \mathrm{l}$, R3 tetap, tidak mengalami penurunan atau kenaikan. Kadar khlorida pada R1 dan R2 mengalami penurunan yang sama sebesar 8 mg/l (removal 16.67\%), R3 mengalami penurunan sebesar $2 \mathrm{mg} / \mathrm{l}$ (removal 4\%).

3. Analisis Parameter Mikrobiologi

Efisiensi penurunan parameter mikrobiologi air bersih dari baku dibandingkan dengan R1, R2 dan R3 digambarkan dalam grafik pada gambar 7.

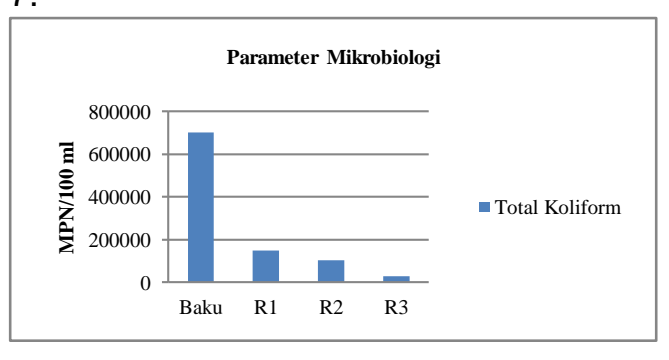

Gambar 7. Grafik Penurunan Parameter Mikrobiologi

Pada gambar 7 menunjukkan penurunan kadar koliform pada R1 sebesar 550000 MPN/100 ml (removal 79\%), R2 sebesar $595000 \mathrm{MPN} / 100 \mathrm{ml}$ (removal 85\%), R3 sebesar 670000 MPN/100 ml (removal $96 \%)$. 


\section{PEMBAHASAN}

1. Analisis Parameter Fisik

Dari data diatas rata-rata efisiensi penurunan parameter warna yang paling besar adalah R1 dan R2 karena nilai R1 dan R2 sama yaitu 35 PtCo, sedangkan pada parameter kekeruhan penurunan yang paling besar adalah R2 yaitu 3.9 NTU. Sehingga R2 mempunyai kemampuan menurunkan kadar warna dan kekeruhan yang paling tinggi, hal ini dikarenakan debit pada R2 sebesar $0.00093 \mathrm{l} / \mathrm{dt}$ paling lambat jika dibandingkan dengan R1 dan R3 yang mempunyai debit sebesar $0.005 \mathrm{l} / \mathrm{dt}$ dan $0.0028 \mathrm{l} / \mathrm{dt}$ sehingga mempermudah pembentukan biofilm dan juga lapisan schmutzdecke pada media yang pada akhirnya akan membantu proses penyisihan partikel-partikel penyebab warna dan kekeruhan ( Slamet, 2000). Penurunan warna dan kekeruhan disebabkan karena media pasir memiliki pori yang akan terisi oleh partikel-partikel tersuspensi penyebab warna dan kekeruhan. Jika rongga-rongga dalam media telah terisi maka lubang pori pun akan menyempit sehingga partikel yang lebih halus dapat tertahan. Mikroorganisme yang mulai tumbuh pada permukaan media dimana merupakan efek proses biofilter juga ikut berperan dalam menurunkan kekeruhan yang tersuspensi.

2. Analisis Parameter Kimia

Kadar kimia air hasil filtrasi menunjukkan memenuhi syarat sebagai air bersih. Media dalam reaktor berfungsi dengan baik dan efektif menurunkan kandungan kimia pada air hasil olahan IPAL. Penurunan parameter air bersih tertinggi pada R1 adalah kadar ammonia dimana menurun sebesar $2.81 \mathrm{mg} / \mathrm{l}$ dari $2.87 \mathrm{mg} / \mathrm{l}$ menjadi $0.06 \mathrm{mg} / \mathrm{l}$ sedangkan penurunan parameter air bersih tertinggi pada R2 yaitu pada kadar sulfat sebesar $19.54 \mathrm{mg} / \mathrm{l}$ dari $54.37 \mathrm{mg} / \mathrm{l}$ menjadi 34.83 $\mathrm{mg} / \mathrm{l}$, kadar nitrat menurun sebesar 9.54 $\mathrm{mg} / \mathrm{l}$ dari $9.95 \mathrm{mg} / \mathrm{l}$ menjadi $0.41 \mathrm{mg} / \mathrm{l}$, kadar besi menurun sebesar $0.09 \mathrm{mg} / \mathrm{l}$ dari $0.14 \mathrm{mg} / \mathrm{l}$ menjadi $0.05 \mathrm{mg} / \mathrm{l}$ dan kadar flourida menurun sebesar $0.17 \mathrm{mg} / \mathrm{l}$ dari $0.38 \mathrm{mg} / \mathrm{l}$ menjadi $0.21 \mathrm{mg} / \mathrm{l}$. Penurunan parameter air bersih tertinggi pada R3 pada kadar mangan sebesar $0.35 \mathrm{mg} / \mathrm{l}$ dari $0.35 \mathrm{mg} / \mathrm{l}$ menjadi $0 \mathrm{mg} / \mathrm{l}$ dan kadar seng menurun sebesar 0.045 $\mathrm{mg} / \mathrm{l}$ dari $0.12 \mathrm{mg} / \mathrm{l}$ menjadi $0.075 \mathrm{mg} / \mathrm{l}$.
Pada R1 yang berisi pasir silika, zeolit dan karbon aktif efektif menurunkan kadar ammonia. R2 yang berisi pasir silika, manganese greensand dan karbon aktif efektif menurunkan sulfat, nitrat, besi dan flourida. Sedangkan R3 yang berisi pasir silika, zeolit, manganese greensand dan karbon aktif efektif menurunkan kadar mangan dan seng.

3. Analisisi Parameter Mikrobiologi

Air hasil olahan IPAL pada penelitian ini memiliki kadar koliform yang sangat tinggi yaitu $7.10^{5} \mathrm{MPN} / 100 \mathrm{ml}$, hal ini disebabkan pada proses pengolahan IPAL tidak ada proses desinfeksi. Air hasil olahan IPAL setelah dilakukan proses filtrasi pada masing-masing reaktor dapat menurunkan kadar koliform. Seperti pada gambar 7 penurunan kadar mikrobiologi koliform pada R1, R2, R3 sebesar $1,5.10^{5} \mathrm{MPN} / 100 \mathrm{ml}, 1,05.10^{5}$ MPN / $100 \mathrm{ml}$, dan $3.10^{4} \mathrm{MPN} / 100 \mathrm{ml}$. R3 efektif menurunkan kadar koliform sebesar $6,7.10^{5} \mathrm{MPN} / 100 \mathrm{ml}$ dari $7.10^{5}$ MPN/100 ml menjadi $3.10^{4} \mathrm{MPN} / 100 \mathrm{ml}$. Walaupun efisiensi penurunan kadar koliform hasil filtrasi dari R3 tinggi, namun masih belum memenuhi syarat kualitas air bersih, masih perlu dilakukan desinfeksi sehingga bebas dari koliform sebagai syarat dalam kualitas air bersih.

\section{KESIMPULAN DAN SARAN Kesimpulan:}

Kondisi air olahan IPAL untuk parameter fisik dan kimia memungkinkan untuk diolah menjadi air bersih tetapi untuk parameter mikrobiologi harus dilakukan pengolahan lebih lanjut karena melebihi baku mutu air bersih. Penurunan parameter fisik dipengaruhi oleh debit aliran reaktor filter sedangkan parameter kimia dan mikrobiologi dapat diturunkan dengan reaktor multi media. Penurunan parameter fisik dan kimia memenuhi baku mutu sedangkan parameter mikrobiologi belum memenuhi standar baku mutu yang ditetapkan oleh Permenkes RI No.416/Menkes/Per/IX/90 tentang syarat air bersih

\section{Saran :}

Tingginya angka koliform pada penelitian ini perlu dilakukan reduksi sehingga bebas dari koliform sebagai syarat dalam kualitas air bersih. Untuk itu perlu dilakukan treatment desinfeksi guna menghilangkan Koliform. 


\section{DAFTAR PUSTAKA}

Anonymous,2002, Pedoman Sanitasi Rumah Sakit Di Indonesia, Departemen Kesehatan Republik Indonesia, Jakarta.

Anonymous,2006, Teknologi Pengolahan Limbah Cair Sistem Biakan Melekat,Prosiding Pelatihan Pengolahan Limbah Cair Oleh BPPT, Jakarta.

Departemen Kesehatan RI, 2004, Peraturan Menteri Kesehatan RI No.1204 Tentang Persyaratan Kesehatan Lingkungan Rumah Sakit,Jakarta.

Alamsjah,2006, Alat Penjernih Air, Kawan Pustaka, Cetakan I, Jakarta.

Kusnaedi, 2010, Mengolah Air Kotor Untuk Air Minum, Penebar Swadaya, Cetakan I, Jakarta.

Said, Nusa Idaman, 2006, Teknologi Pengolahan Limbah Cair Sistem Biakan Melekat (Rumah Sakit, Domestik, Industri) , Pusat Teknologi Lingkungan, Jakarta.

Slamet,A dan Masduqi, A, 2000, Satuan Proses, Jurusan Teknik Lingkungan FTSP-ITS, Surabaya

Wahyu Hidayat, 2009, Daur Ulang Air Limbah Domestik Kapasitas 0.9 m3 per jam Menggunakan Kombinasi Reaktor Biofilter Anaerob aerob Dan Pengolahan Lanjutan, Pusat Teknologi Lingkungan, Jakarta. 